\title{
FLEXURAL CAPACITY AND STIFFNESS OF MONOLITHIC BIAXIAL HOLLOW SLABS
}

\author{
Juozas VALIVONIS, Bronius JONAITIS, Robertas ZAVALIS, Tomas SKUTURNA, Arnoldas ŠNEIDERIS \\ Department of Reinforced Concrete and Masonry Structures, Vilnius Gediminas Technical University, \\ Saulètekio al. 11, 10223 Vilnius, Lithuania
}

Received 22 Nov 2012; accepted 04 Apr 2014

\begin{abstract}
The article presents a research on flexural behaviour of hollow monolithic reinforced concrete slabs. It focuses on the results of experimental investigation into full-size hollow reinforced concrete slabs and analyses their flexural capacity and stiffness. The self-weight of the slabs directly depends on the shape and number of hollows. An increase in the hollowness of a slab significantly reduces the load caused by self-weight. This allows increasing the estimated length of the slab under the same payload. An increase in the amount of hollows of the slab changes the stiffness of the slab crosssection that has a direct impact on slab deflection. Considering the shape of the slab cross-section, theoretical calculations of the flexural capacity and deflection of experimental slabs were made. The design of a new type of slabs and variations in different parameters of the slab experience difficulties in conducting a large amount of experimental tests. Therefore, the initial analysis may apply to numerical simulation. The paper describes the principles of designing a numerical model. The calculations were made using DIANA software. The stiffness and flexural capacity of the hollow slabs were established employing numerical simulation compared to the results of experimental investigations. The findings indicate that numerical simulation can be applied for analysing the stress state of the examined structures.
\end{abstract}

Keywords: monolithic reinforced concrete, slab, hollows, stiffness, flexural capacity, numerical simulation.

\section{Introduction}

A slab is a very important structural member for making a space in a building. Multi-storey buildings are frequently erected using monolithic reinforced concrete. Usually, slabs that are used in buildings are made of reinforced concrete and have a single-piece cross-section structure.

The design of public and industrial buildings frequently requires a large continuous space. In this case, increasing the distance between columns is essential, which expands the space between slab supports. The performance characteristics of reinforced concrete slabs are often determined by the serviceability limit state and satisfied requirements, which increases the slab stiffness. Besides, the stiffness of reinforced concrete slabs can be improved by either using pre-stressed reinforcement or increasing the height of the cross-section of the slab or changing mechanical properties of concrete (Abramski et al. 2010; Santa Cruz Astorqui et al. 2009; Sprince et al. 2011, 2013). Prestressing of reinforcement of monolithic reinforced concrete slabs is a rather complex process and requires expensive equipment and high labour costs. Thus, in construction practice, stiffness is most frequently increased raising the height of the crosssection of reinforced concrete slabs. However, a greater height of the single-piece cross-section results in the loss of useful space and, therefore, increased weight, i.e. the load of the slab. An omission in the reinforced concrete girder slab shows that adding to thickness slightly reduces the deflection of the slab, and in some cases, in large dimensions, even increases it. Hence, to reduce the deflection of monolithic reinforced concrete and girder slabs, other solutions have to be put forward. One of them is a reduction in the weight of the slab leaving the same space between supports and the applied load. Another solution, which is used worldwide involves monolithic reinforced concrete slabs with plastic inserts, which form hollows in slabs. This way, the cross-section of the monolithic reinforced concrete slab becomes analogous to the crosssection of the hollow slab of prefabricated reinforced concrete. The use of such slabs allows overlaying larger openings and increasing the height of the cross-section practically avoiding changes or slightly increasing the loads induced by self-weight. Literature points to the elements forming circular and oval-shaped hollows, the application of which enables to save $20 \%$ and $30 \%$ of concrete, respectively (Fiala, Hajek 2007; Ordon-Beska 2012; Yang et al. 2013; Abramski et al. 2010; Marais et al. 2010; Hai et al. 2013; Chung et al. 2011).

Manufacturing of reinforced concrete structures emits a massive amount of pollutants to the environment. A decrease in the amount of concrete used for producing reinforced concrete slabs of buildings reduces the volume of cement. Production of 1 ton of cement results in $500 \mathrm{~kg} \mathrm{CO} 2$ emitted to the environment. The manufacture of hollow reinforced concrete slabs results in reduction of 
the required amount of concrete, which at the same time lowers the cement consumption. This only indicates that rational decisions on reinforced concrete structures can significantly cut down energy and raw material input, thus reducing environmental pollution (Fiala, Hajek 2007; Abramski et al. 2010). Plastic inserts made for shaping hollows in slabs can be produced from household plastic waste, which is an environmentally-friendly waste management solution.

Plastic inserts used for shaping hollows change the behaviour of reinforced concrete slabs affected by an external load. Upper and lower shelves as well as twoway reinforced concrete edges are designed in such slabs during their production. The two-way edges in a slab change the stiffness of the cross-section at the transverse reinforced concrete edge and between the edges (beside plastic inserts). Thus, the stiffness and deflection of the above-mentioned slabs partially depend on variations in stiffness along the slab.

The article explores the stiffness and flexural strength of reinforced concrete slabs with hollows close to the square cross-section.

Research on experimental and numerical simulations was carried out to find out the behaviour of a reinforced concrete slab with plastic inserts in operation, to monitor crack formation and development, and to display the character of a fracture.

\section{Experimental slabs and a scheme for testing}

For the experimental research, two reinforced concrete slabs were manufactured. The thickness of the slab amounts to $300 \mathrm{~mm}$. The overall image and layout of hollows in the slab using plastic inserts are shown in Figure 1. The height of oval-shaped plastic inserts is $180 \mathrm{~mm}$. The measurements of insert are displayed in Figure 2. The thickness of the designed concrete layer beside plastic inserts is $60 \mathrm{~mm}$. The slabs were concreted at two stages. The first stage included concrete poured at the height of the slab, which was $100 \mathrm{~mm}$; whereas at the second stage, it was $200 \mathrm{~mm}$. Class C25/30 concrete was used to produce slabs. A scheme for slab reinforcement is presented in Figure 1b. The main reinforcement is concentrated on the edges between plastic inserts, and the distance between longitudinal reinforced bars is $415 \mathrm{~mm}$. The diameter of the reinforcement is $25 \mathrm{~mm}$. Plastic inserts in the slabs were arranged applying constructive reinforcement frame of $5 \mathrm{~mm}$ in diameter (Fig. 2).

The average values and weight of the geometrical characteristics of the slabs are displayed in Table 1.

Table 1. Characteristics of the slab

\begin{tabular}{c|c|c|c|c}
\hline Slab & $\begin{array}{c}\text { Length, } \\
\mathrm{mm}\end{array}$ & $\begin{array}{c}\text { Width, } \\
\mathrm{mm}\end{array}$ & $\begin{array}{c}\text { Thickness, } \\
\mathrm{mm}\end{array}$ & $\begin{array}{c}\text { Weight, } \\
\mathrm{kg}\end{array}$ \\
\hline P1 & 5996 & 2961 & 301 & 8750 \\
\hline P2 & 6001 & 2962 & 302 & 9200 \\
\hline
\end{tabular}

a)

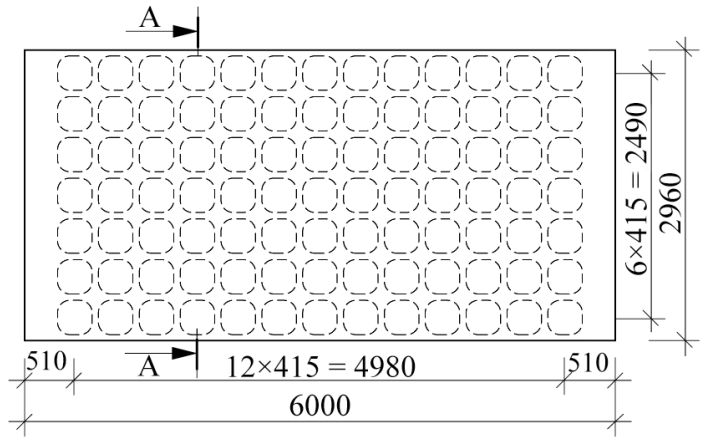

b)

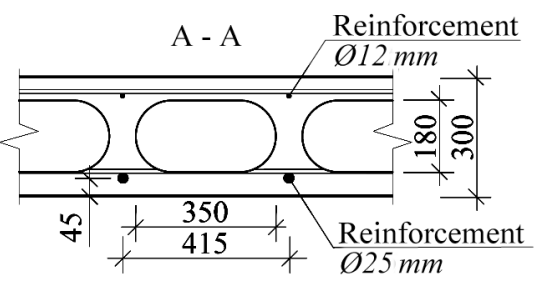

c)

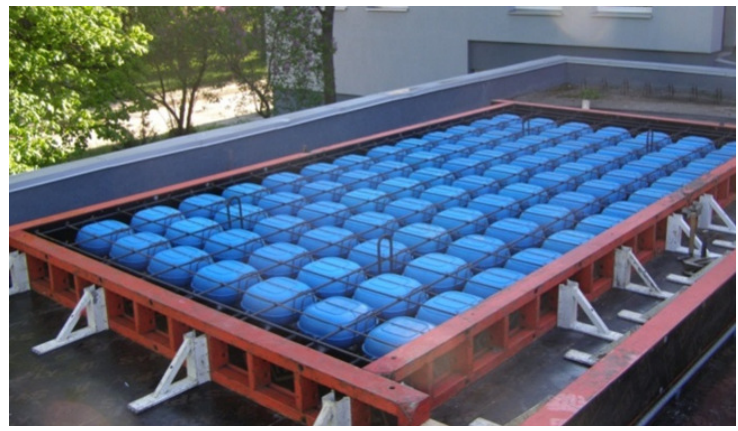

Fig. 1. The overall image of a specimen: a) the scheme of slab; b) slab cross section; c) the layout of plastic inserts

a)

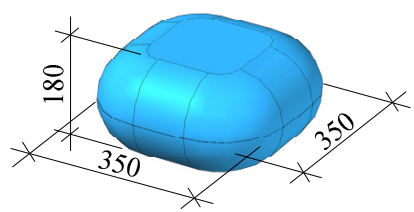

b)

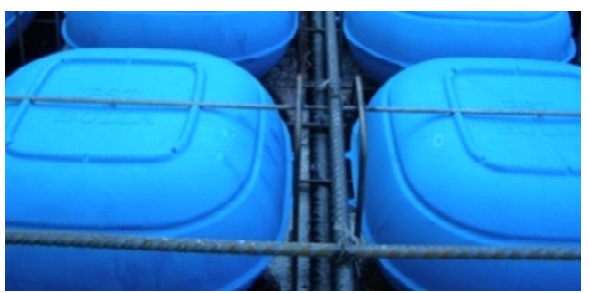

Fig. 2. Plastic inserts of the slab: a) insert; b) insert fixing view

The concrete of the produced slab was hardened under real conditions. The tested slabs were loaded with two concentrated forces. The load over the slab was transferred via rigid steel girders. The girder and the slab were separated by the levelling cement mortar layer of $100 \mathrm{~mm}$ with (Fig. 3). 
a)

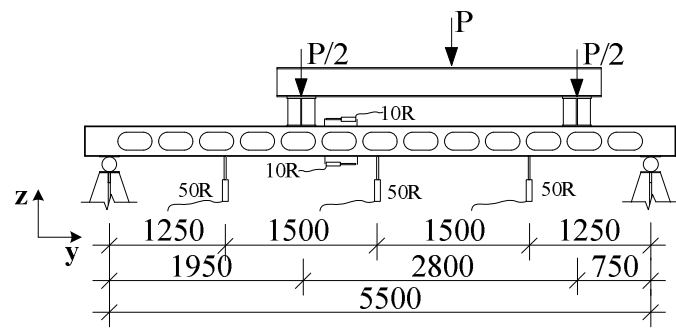

b)

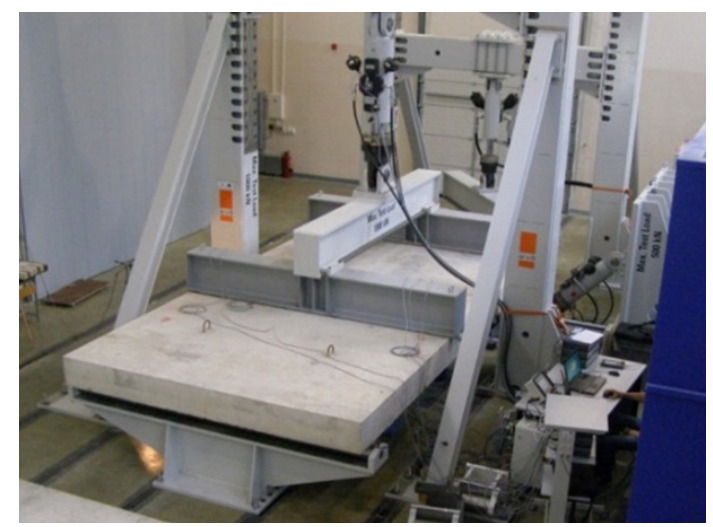

Fig. 3. Slab testing: a) testing scheme; b) testing view

The tested slabs were loaded periodically. The load during the first stage made $70 \%$ of the designed destructive load and was equal to $371 \mathrm{kN}$. The slabs were unloaded before the second stage. The load during the second stage was increased from 0 to the fracture of the slab. The load was increased gradually. The value of the load of the step amounted to 0.1 of the designed destructive load $(\Delta \mathrm{P}=53 \mathrm{kN})$. At every step, the load was maintained for 5 min.

Slab deflections, strains of compressed concrete and the tensile zone as well as the width of the crack were measured during each tested stage. Deflections were measured at the middle of the slab and $1500 \mathrm{~mm}$ away from the middle in both directions. The arrangement of measuring equipment is shown in Figure 3a.

Slab experiments were conducted applying the universal test stand (Fig. 3b). The samples affected by the acting force during the performed test, strains and slab deflections were recorded with the help of universal electronic testing equipment PCS 800 Walter-bai. Deflection and strains were measured employing LVDT 50R and LVDT 10R inductive tensometers, respectively.

\section{Results of experimental research on slabs}

Mechanical properties of concrete were established testing cubes, cylinders and prisms. Concrete samples, similarly to reinforced concrete slabs, were stored under the same conditions. Testing was carried out with reference to standard requirements EN12390-3 established in 2009. Testing of cylinders involves measuring longitudinal concrete strains. The test results have assisted in establishing compressive concrete strength $f_{c m}$ and elasticity modulus $E_{c m}$. The flexural strength of concrete was found while testing rectangular prisms. With reference to flexural strength and according to Model Code 90 (MC90
1993) recommendations, the average tensile strength $f_{c t m}$ was set. The samples and slabs of the same span were tested. The tests of the reinforced bars used for slab reinforcement disclosed that the average reinforcement yield stresses $f_{y m}$ of the bars of $25 \mathrm{~mm}$ in diameter makes $534 \mathrm{MPa}$, whereas the bars of $12 \mathrm{~mm}$ in diameter reach $550.3 \mathrm{MPa}$. Results of the research on the mechanical properties of concrete and reinforcement are presented in Table 2.

Table 2. Mechanical properties of concrete slabs

\begin{tabular}{l|c}
\hline \multicolumn{1}{c|}{ Parameter } & Value, MPa \\
\hline Average strength of concrete cubes $f_{c, c u b e}$ & 37,5 \\
\hline Average strength of concrete cylinders $f_{c m}$ & 34,1 \\
\hline Average tensile strength of concrete $f_{c t m}$ & 2,8 \\
\hline Concrete elasticity module $E_{c m}$ & $31 \times 10^{3}$ \\
\hline Reinforcement Ø25 $\mathrm{mm} f_{v m}$ & 534 \\
\hline Reinforcement Ø12 $\mathrm{mm} f_{v m}$ & 550 \\
\hline
\end{tabular}

According to the scheme offered in Figure $3 a$, the fracture of both slabs has taken place in the perpendicular cross-section close to the place of one of the added forces, i.e. in the cross-section where the maximum bending moment is acting. Both slabs fractured under the effect of a bending moment (Fig. 4). The fracture occurred after reinforcement in the tensile zone reached yield stresses and concrete stresses of the compressive zone achieved compressive yield strength. Close to the support affected by greater share force, oblique cracks occurred; however, they were insufficiently wide and, therefore, could have not caused any danger. Experimental forces destructing the slabs are shown in Table 3.

a)

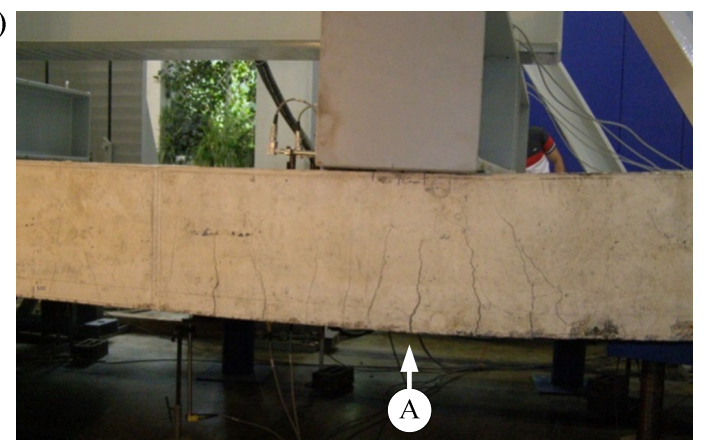

b)

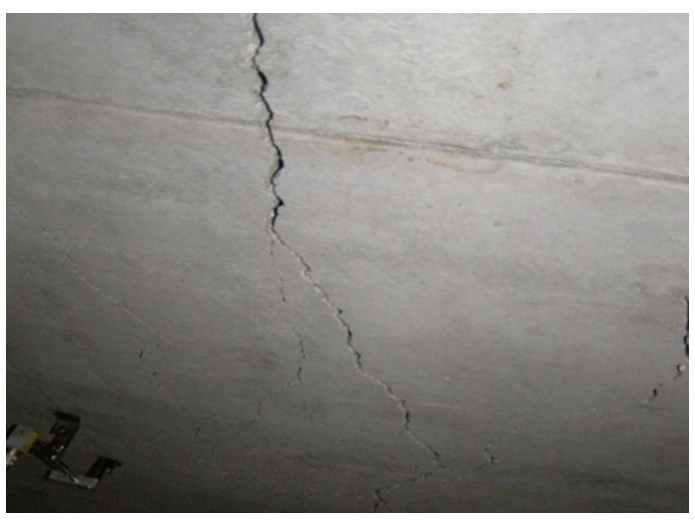

Fig. 4. A fracture of the slab: a) general view; b) view of a fracture in the tensile zone 
Table 3. Results of slab testing

\begin{tabular}{|c|c|c|c|c|}
\hline \multirow[t]{2}{*}{ Slab } & \multicolumn{2}{|c|}{$\begin{array}{l}\text { Slab deflection } \omega_{o b s} \mathrm{~mm} \text {, } \\
\text { when } P=0.6 P_{d}, * *\end{array}$} & \multirow{2}{*}{$\begin{array}{l}\text { Destructive } \\
\quad \text { load } \\
P_{u, o b s}, \mathrm{kN}\end{array}$} & \multirow{2}{*}{$\begin{array}{c}\text { Destructive } \\
\text { bending } \\
\text { moment } \\
M_{u, o b s} \\
\text { kNm }\end{array}$} \\
\hline & $\begin{array}{l}\text { First } \\
\text { stage of } \\
\text { loading }\end{array}$ & $\begin{array}{l}\text { Second } \\
\text { stage of } \\
\text { loading }\end{array}$ & & \\
\hline P1 & 17.6 & 18.2 & 794* & 588.4 \\
\hline P2 & 18.2 & 20.9 & $789^{*}$ & 583.1 \\
\hline \multicolumn{5}{|c|}{$\begin{array}{l}* \text { loads are provided following evaluation of the self- } \\
\quad \text { weight of the slab; } \\
* * \quad \text { - designed destructive load. }\end{array}$} \\
\hline
\end{tabular}

Apart from preliminary reinforcement stress, the withstood load of reinforced concrete slabs is frequently determined by a deflection rather than flexural capacity. Thus, the tests measured slab deflection at 6 points. A scheme for deflection measurements is shown in Figure $3 \mathrm{a}$. The results of measured slab deflections are presented in Figure 5.

The slab loaded with up to $70 \%$ of the destructive load and then unloaded ( $1^{\text {st }}$ stage of loading) shows that the remaining strains (deflection) of slabs P1 and P2 make $3.5 \mathrm{~mm}$ and $1.8 \mathrm{~mm}$, respectively. The data of slab testing disclosed that the maximum deflections of slabs $\mathrm{P} 1$ and $\mathrm{P} 2$, when reinforcement stress reaches the yield point, are equal to $37.7 \mathrm{~mm}$ and $42.2 \mathrm{~mm}$, respectively.

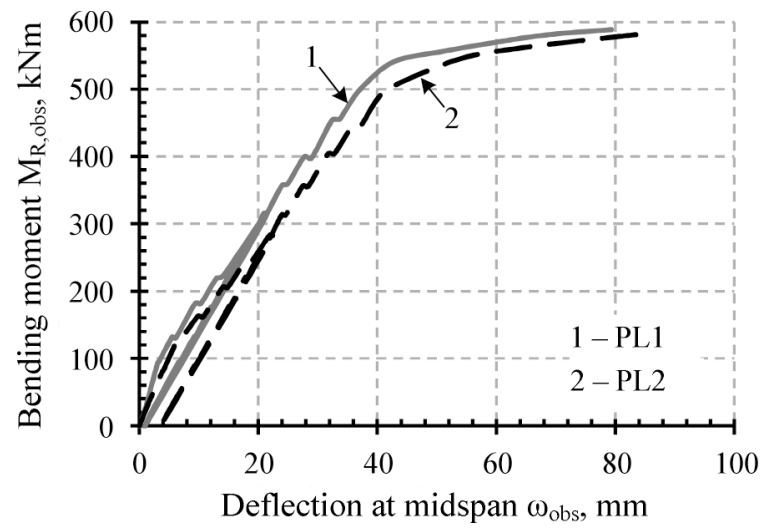

Fig. 5. The deflection-bending moment dependence of slab P1 and $\mathrm{P} 2$ in the middle of the slab

Deflection is usually evaluated when the structure is affected by a characteristic load, which is approximately equal to $60 \%$ of the designed destructive load $\left(P_{d}\right)$, considering which the load should agree with $\mathrm{P}=370 \mathrm{kN}$. Therefore, the deflection was established under the effect of such load. The samples loaded up to the fracture $\left(2^{\text {nd }}\right.$ stage of loading) indicate that the deflection of slabs P1 and $\mathrm{P} 2$ beside the mid-span were equal to $18.2 \mathrm{~mm}$ and 20.9 , respectively, and made $L / 302$ and $L / 263$, with $L$ as the calculated span length of the experimental slab.

Testing included the measurements of the strains of compressive and tensile concrete. The strains of compressive and tensile concrete used for the slabs were measured at the mid-span and the added power point. The average strains of the compressive concrete of the slab and the average strains of the reinforcement of the tensile zone in the same cross-section are presented in Figure 6. Tensile strains were measured at the bottom of the slab.

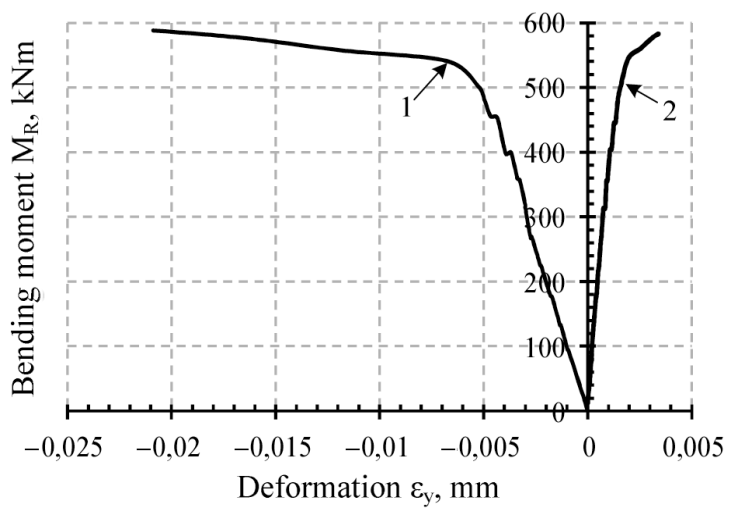

Fig. 6. The average longitudinal bending moment-strain dependence of the slab PL-1: 1 - in the tensile zone of the slab; 2 - in the compressive zone of the slab

\section{Results and main assumptions for slab calculations}

The calculation of the flexural capacity and stiffness of hollow monolithic reinforced concrete slabs takes place through changing the actual cross-section of the slab into the effective one. The actual cross-section of the slab is most frequently replaced by the I-section (Fig. 7). The use of inserts for formation of spherical-shape hollows makes the creation of an effective cross-section more complicated (Gumilang Jati 2013; Hai et al. 2013). In that case, when square inserts have slightly rounded corners, i.e. the rounding radius is small, for investigating flexural capacity or calculating longitudinal reinforcement, the calculated I-section can be accepted, where the edge width $b_{w}$ and flange height $h_{f}$ are equal to the actual width of the slab edge and flange thickness in the thinnest places (Fig. 7b).

For examining the stiffness of the slab, the edge width of the effective T-cross-section and the thickness of the flange can be accepted as $b_{w}=b_{w 1}, h_{f 1}=h_{f 1.1}$ and $h_{f 2}=h_{f 1.2 .1}$ (Fig. 7c).

a)

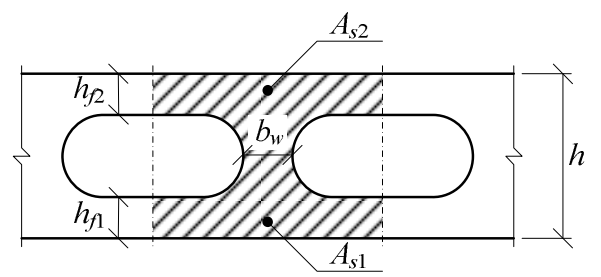

b)

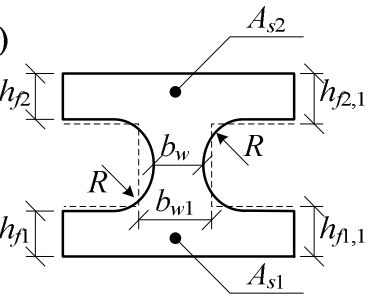

c)

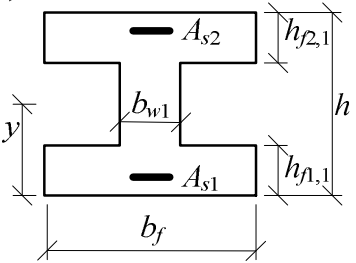

Fig. 7. The cross-section of the hollow monolithic reinforced concrete slab: a) actual; b) effective, calculating flexural capacity; c) effective, calculating stiffness 
When applying effective cross-sections, the flexural capacity and stiffness of the slab are determined according to general principles used for calculating reinforced concrete structures. The principles are laid down in design standards EN 1992-1-1 of reinforced concrete structures.

Having accepted the effective cross-section (Fig. 7b) according to EN 1992-1-1 calculating methodology and having evaluated the actual strength of concrete and reinforcement (Table 2), flexural capacity equal to $M_{R, c a l}=632 \mathrm{kNm}$ was determined. Slab deflection was found (Fig. 7c) having accepted the effective crosssection and having evaluated the actual module of concrete elasticity (Table 2) and cracks. The worked out slab deflection, under the load-making $60 \%$ of the designed destructive load, is $\omega_{\text {cal }}=19 \mathrm{~mm}$.

For verifying calculation pre-conditions, experimental research on the flexural capacity and stiffness of the hollow monolithic reinforced concrete slab working in one direction was carried out.

\section{Numerical simulation of the state of stress in slabs}

The conducted research disclosed (Schnellenbach-Held, Pfeffer 2002; Balevičius, Marčiukaitis 2013; Gribniak et al. 2010; Sergiu, C., Sergiu, B. 2011) that the numerical simulation of the structure allows analysing the stress state of formations and forecasting the behaviour under loading.

To properly identify the flexural capacity of the slab, it is necessary to accurately assess the distribution of cross-sectional stresses at the investigated stage. For analysing the stress state of the slab, numerical simulation was applied and completed using Diana software. The numerical model of the examined hollow slab was developed accurately designing the elements forming hollows as well as describing the reinforcement of tensile and compressive zones. For investigating stress distribution in the cross-section of the slab, a dense mesh of finite elements is required. To reduce computation time, the slab section symmetrical in two planes was studied. The mesh of finite elements is made from isoparametric six-node solid wedge and eight-node solid brick elements. The mesh of finite elements of the examined slab (numerical simulation) is shown in Figure 8. Boundary conditions and a loading scheme were accepted according to the slab testing plan (Fig. 3).

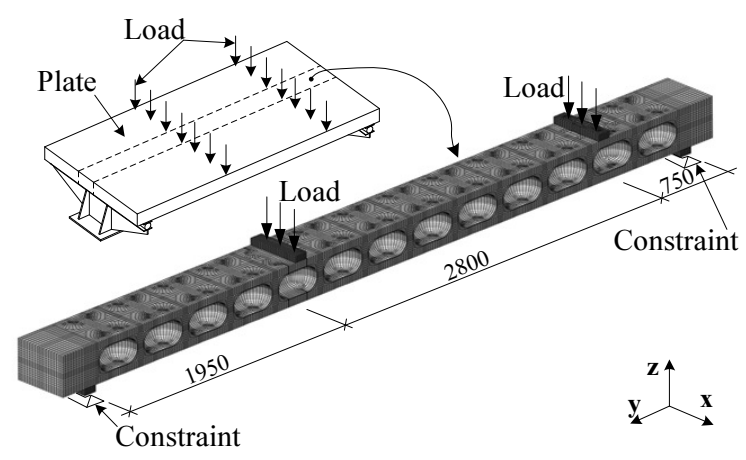

Fig. 8. Scheme for a numerical model
Reinforcement bars are designed as elements lacking embedded reinforcement. They relate to the basic elements of the concrete part of the cross-section. Diana software automatically reduces the stiffness of these elements that depend on the parameters of the elements of the reinforcement bars crossing the basic concrete element (TNO DIANA 2011).

The behaviour of the slab is described using the model of the total strain based on the principles of the smeared crack method. The introduced model evaluates variations in the stress and strain state and can be referred to as to the fixed stress strain concept. Tensile and compressive stresses are characterized as strain-dependant functions.

The behaviour of concrete under compression was defined employing parabolic dependence (TNO DIANA 2011) (Fig. 9a). The compressive energy of a fracture $G_{f c}$ was calculated with reference to the dependence suggested in works by Lourenço (1996) and Sandoval, Roca (2012):

$$
G_{f_{c}}=15+0.43 f_{c}-0.0036 f_{c}^{2},
$$

where: $f_{c}$ - accepted average cylindrical compressive strength of concrete. a)

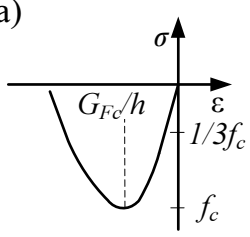

b)

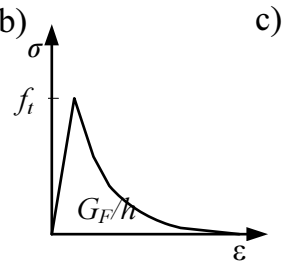

c)

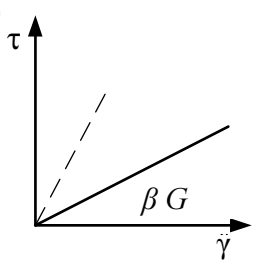

Fig. 9. Material models applied for concrete: a) compression; b) tension; c) model for share

The behaviour of the tensioned concrete was described employing an exponential dependence assessing the strength of the tensioned concrete and fracture energy (TNO DIANA 2011) (Fig. 9b). Tensile fracture energy was established according to Model Code 90 (MC90 1993) - the dependence of compressive strength and fracture energy under tension:

$$
G_{F}=0.03\left(f_{c m} / 10\right)^{0.7},
$$

where: $f_{c m}$ - the average compressive strength of concrete set according to (EN 1992-1-1 (EC2)). This dependence is applied when concrete filling makes less than $16 \mathrm{~mm}$.

The behaviour of concrete between cracks under shearing stress was defined using the constant reduction factor (Fig. 9c).

Crack band width $h$ presented in Figure 9 depends on the size of finite elements. Software Diana provides its automatic evaluation.

The mechanical characteristics of reinforcement steel were described employing the von Mises condition of elasticity. The parameters of the mechanical properties 
of all materials, applying the numerical model, are shown in Table 4.

Table 4. The values of the parameters of the materials used in the numerical model

\begin{tabular}{l|c|c}
\hline \multirow{2}{*}{ Parameters } & \multicolumn{2}{|c}{ Material } \\
\cline { 2 - 3 } & Concrete & Steel \\
\hline Compressive force $f_{c}, \mathrm{~N} / \mathrm{mm}^{2}$ & 38 & - \\
Tensile force $f_{t}, \mathrm{~N} / \mathrm{mm}^{2}$ & 2.5 & - \\
Tensile fracture energy, $G_{F}$, & 0.076 & - \\
Nmm/mm & & \\
Compressive fracture energy, $G_{f c}$, & 26.2 & - \\
Nmm/mm & & \\
Elasticity modulus $E \times 10^{-3}, \mathrm{~N} / \mathrm{mm}^{2}$ & 32 & 200 \\
Poisson's ratio, $v$ & 0.22 & 0.3 \\
Yield strength $f_{y}, \mathrm{~N} / \mathrm{mm}^{2}$ & - & 535 \\
\hline
\end{tabular}

Having implemented the numerical model of the bent slab, the dependence of the deflection of the bending moment and stress distributions at different stages of loading was received (Fig. 10). This allows analysing the behaviour of the bent monolithic reinforced concrete hollow slab from the start of loading to the fracture. The results of numerical modelling are presented in Figures 10 to 14 .

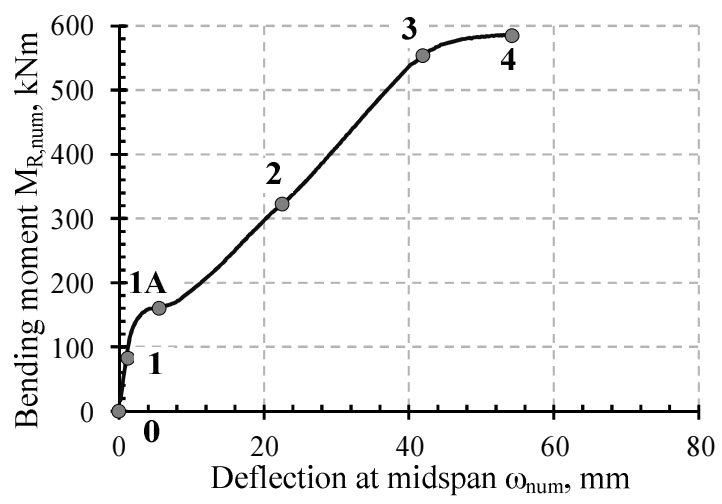

Fig. 10. Chart of the bending moment and the deflection from numerical modelling

The chart displaying slab deflections (Fig. 10) distinguishes four basic stages reflecting the behaviour of the slab. During the $1^{\text {st }}$ stage, slab deflection is linearly proportional to the added load. Therefore, it can be maintained that, at this stage, the slab is elastic (Fig. 10, part $0-1$ ), and normal stresses in the cross-section vary accordingly to linear dependence (Fig. 11). During the $2^{\text {nd }}$ stage (Fig. 10, part 1-2), when concrete stresses reach threshold value $f_{t}$ in the tension zone, the first crack appears. This stage is composed of two parts: section 1-1A and section 1A-2. Point 1A defines stresses under crack formation (Fig. 12). The nature of stress distribution in the tensile zone indicates that concrete works in the decreasing part of stress-strain diagram of the tensioned concrete. A gradual increase in the load (section 1A-2) results in the new crack and widens the existing ones (Fig. 13). Point 2 (load makes $60 \%$ of the destructive a)
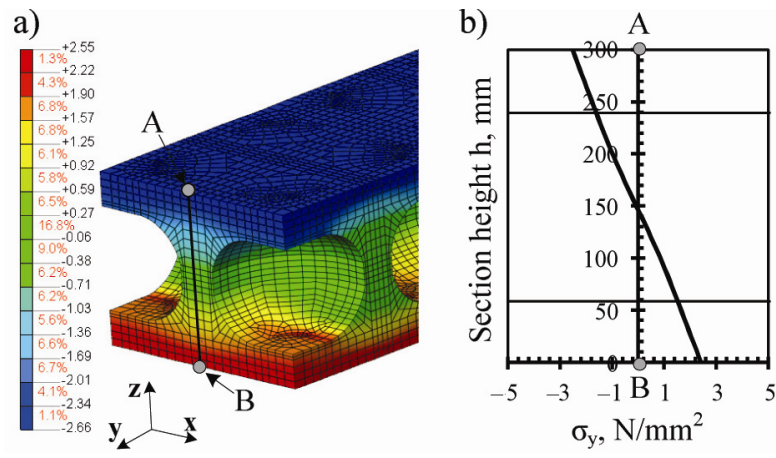

Fig. 11. Stress distribution in the concrete of the slab crosssection, point 1: a) overall image; b) graphic image a)

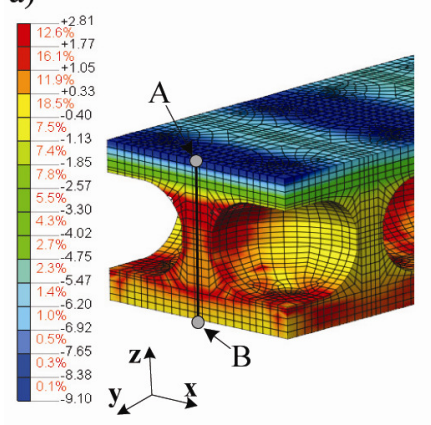

b)

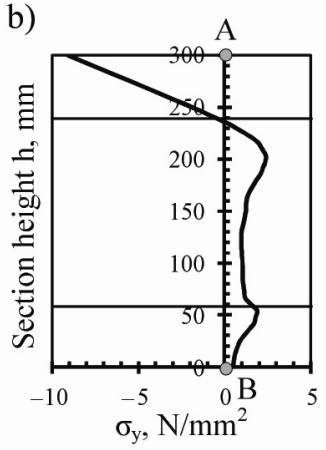

Fig. 12. Stress distribution in the concrete of the slab crosssection, point 1A: a) overall image; b) graphic image a)

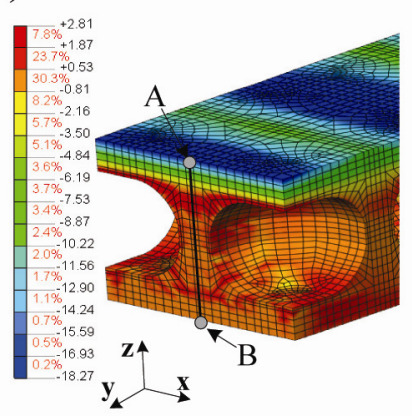

b)

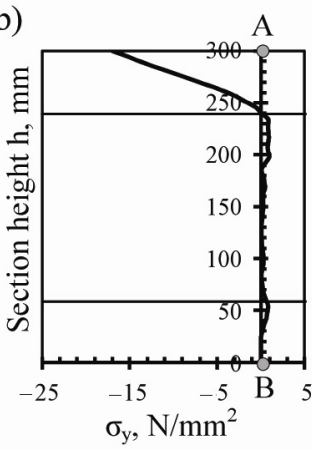

Fig. 13. Stress distribution in the concrete of the slab crosssection, point 2: a) overall image; b) graphic image a)

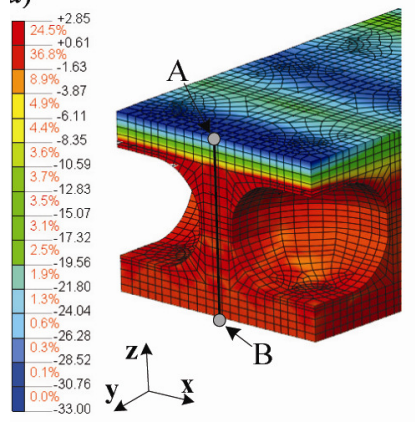

b)

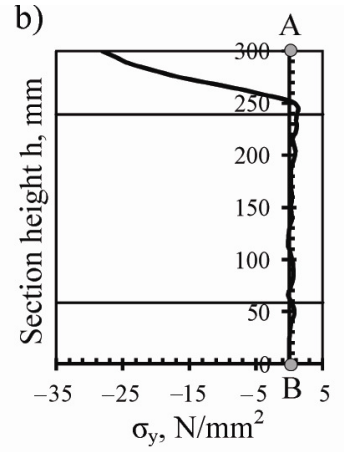

Fig. 14. Stress distribution in the concrete of the slab crosssection, point 3: a) overall image; b) graphic image 
load) describes the action of the slab close to the serviceability limit state. A further rise in the load (Fig. 10, section 2-3) does not result in forming new cracks, as those that appeared at earlier stages develop (opening and height increase) and, therefore, the height of the compressive zone decreases. This stage lasts until reinforcement stresses arrive to the yield point. Yield stress formation in reinforcement is shown by the $3^{\text {rd }}$ deflection point presented in the diagram (Fig. 10). Further, the load slightly increases (Fig. 10, section 3-4) until the concrete of the compressive zone is fractured. The $4^{\text {th }}$ point in the diagram appears as the fracture of the bent monolithic hollow slab. The diagram of stresses (Fig. 14) clearly shows that the real height of the compressive zone is within the boundaries of the upper flange of the slab.

The obtained results of numerical simulation disclosed that compressive stresses are unevenly distributed in the upper flange of the slab. The highest compressive stresses on the flange of the slab can be observed beside the middle of the inserts, and this zone experiences cracks in the tension zone and maximum stresses in reinforcement.

\section{Comparison of experimental and theoretical results}

The obtained results of experimental research on the stiffness and flexural capacity of hollow reinforced concrete slabs were compared with numerical simulation and theoretical calculations. The received deflection curves of experimental research and numerical simulation are presented in Figure 15.
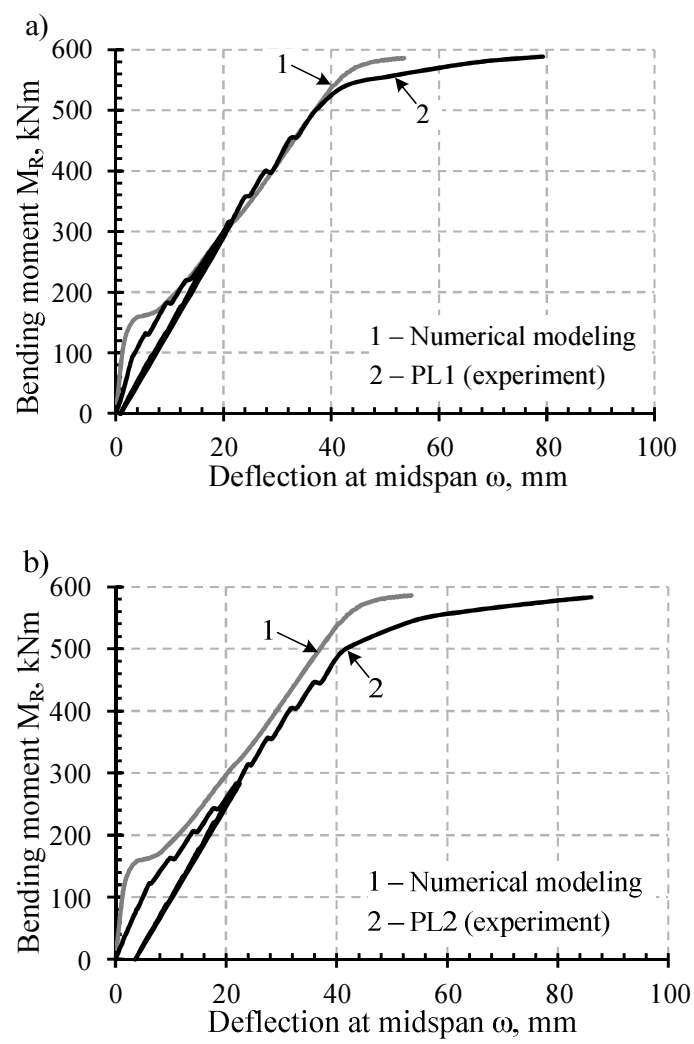

Fig. 15. Charts of the bending moment and deflection: a) slab P1; b) slab P2. 1 - curve of numerical modelling, 2 - experimental curve
A comparison of deflection curves draws a fairly good agreement of both slab deflection and destructive force (flexural capacity). A slight difference at the initial stage of slab loading can be observed (up to $152 \mathrm{kNm}$ ). This is due to the fact that initial micro-cracks weren't evaluated while making the numerical model. They weren't assessed, because the performed research was aimed at estimating the behaviour of the reinforced concrete slab under operational and fracture loads. Experimental deflections of the slabs $\omega_{o b s}$ were compared with the deflections of numerical simulation $\omega_{\text {mum }}$ and theoretical calculations $\omega_{E N}$ according to EN 1992-1-1 methodology. The received results are shown in Table 4. On average, the difference between the results of numerical simulation and theoretical calculations and experimental values makes $10 \%$ and $7 \%$, respectively.

Table 4. Comparison of research on slab deflections

\begin{tabular}{|c|c|c|c|c|c|}
\hline \multirow[t]{3}{*}{ Slab } & \multicolumn{3}{|c|}{ Deflections, mm } & \multirow{3}{*}{$\frac{\omega_{\text {obs }}}{\omega_{\text {num }}}$} & \multirow{3}{*}{$\frac{\omega_{o b s}}{\omega_{E N}}$} \\
\hline & \multirow{2}{*}{$\begin{array}{c}\text { Experimental } \\
\omega_{o b s} *\end{array}$} & \multicolumn{2}{|c|}{ Calculated } & & \\
\hline & & $\omega_{m u m}{ }^{*}$ & $\omega_{E N^{*}}{ }^{*}$ & & \\
\hline P1 & 18.2 & \multirow{2}{*}{17.7} & \multirow{2}{*}{19} & 1.03 & 0.96 \\
\hline $\mathrm{P} 2$ & 20.9 & & & 1.18 & 1.1 \\
\hline \multicolumn{6}{|c|}{$\begin{array}{l}* \text { deflections were determined under the load making } 60 \% \text { of } \\
\text { the designed destructive load. }\end{array}$} \\
\hline
\end{tabular}

Experimental flexural capacity $M_{R, o b s}$ was compared with flexural capacity established applying numerical simulation $M_{R, n u m}$ and calculated employing EN 1992-1-1 methodology $M_{R, E N}$. The obtained results are displayed in Table 5. Flexural capacity found employing numerical simulation agrees with the values determined through the conducted experiments. The difference between flexural capacities determined with reference to EN 1992-1-1 methodology and that estimated by experiments makes up to $8 \%$.

Table 5. Comparison of the results of research on the flexural capacity of the slab

\begin{tabular}{|c|c|c|c|c|c|}
\hline \multirow{3}{*}{ Slab } & \multicolumn{3}{|c|}{ Flexural capacity, $\mathrm{kNm}$} & \multirow{3}{*}{$\frac{M_{R, \text { obs }}}{M_{R, \text { num }}}$} & \multirow{3}{*}{$\frac{M_{R, o b s}}{M_{R, E N}}$} \\
\hline & \multirow{2}{*}{$\begin{array}{c}\text { Experi- } \\
\text { mental } \\
M_{R, o b s}{ }^{*}\end{array}$} & \multicolumn{2}{|c|}{ Calculated } & & \\
\hline & & $M_{R, \text { num }}{ }^{*}$ & $M_{R, E N^{*}}$ & & \\
\hline $\mathrm{P} 1$ & 588.4 & \multirow{2}{*}{586} & \multirow{2}{*}{632} & 1.0 & 0.93 \\
\hline $\mathrm{P} 2$ & 583.1 & & & 0.99 & 0.92 \\
\hline
\end{tabular}

Theoretical and experimental research disclosed that for investigation into the behaviour of the hollow monolithic reinforced concrete slab, the numerical simulation method can be successfully applied.

\section{Conclusions}

The use of plastic inserts for shaping hollows in the manufacture of monolithic reinforced concrete slabs allows reducing concrete input by $20-40 \%$ compared to similar slabs having a continuous cross-section and the same dimensions. A decrease in cement input results in a re- 
duction in carbon dioxide released to the atmosphere. Plastic inserts use for shaping hollows are produced from plastic waste, which together with decreased input contribute to environmental protection.

The inserts used for shaping hollows cut down the self-weight of the slab, thus insignificantly changing the stiffness of the structure. The experiments on hollow monolithic slabs disclosed that under an operational load, the average deflection of the slab made on average $L / 280$, which is less than the allowed relative deflection of $L / 250$.

The deflection established using numerical simulation and calculated according to EN 1992-1-1 methodology changing the real cross-section into the equivalent one has a fairly good agreement with the results of experimental research. The results of numerical modelling and theoretical calculations differ from experimental values by $10 \%$ and $7 \%$, respectively.

The flexural capacity of hollow monolithic slabs found applying numerical simulation completely agrees with the values set by the conducted experiments, whereas the difference between flexural capacities calculated according to EN 1992-1-1 methodology and determined with the help of the performed experiments makes up to $8 \%$.

Experimental and theoretical investigation into the behaviour of hollow monolithic slabs demonstrated that the flexural capacity and deflections of such slabs can be worked out with reference to EN 1992-1-1 methodology changing the actual cross-section with the effective one.

A good agreement of the results of numerical simulation and experimental research indicates that numerical simulation can be successfully applied for predicting the flexural capacity and stiffness of hollow monolithic slabs. This allows, while designing similar structures, to analyse their behaviour and reduce the volume of experimental research.

\section{Acknowledgements}

This work was funded by the European Social Fund Agency, Project No. VP1-3.1-MES-10-V-02-006.

\section{References}

Abramski, M.; Albert, A.; Pfeffer, K.; Schnell, J. 2010. Experimentelle und numerische Untersuchungen zum Tragverhalten von Stahlbetondecken mit kugelförmigen Hohlkörpern, Beton- und Stahlbetonbau 105(6): 349-361. http://dx.doi.org/10.1002/best.201000031

Balevičius, R.; Marčiukaitis, G. 2013. Linear and non-linear creep models for a multi-layered concrete composite, $A r-$ chives of Civil and Mechanical Engineering 13(4): 472490.

Chung, J. H.; Choi, H. K.; Lee, S. C.; Choi, C. S. 2011. Shear capacity of biaxial hollow slab with donut type hollow sphere, Procedia Engineering 14: 2219-2222. http://dx.doi.org/10.1016/j.proeng.2011.07.279

EN 1992-1-1: 2005. Design of concrete structures - Part 1-1: General rules and rules for buildings.

EN 12390-3: 2009. Testing hardened concrete - Part 3: Compressive strength of test specimens.
Fiala, C.; Hajek, P. 2007. Environmentally based optimization of RC slab floor structures, CESB 07 Conference Proceedings, 24-26 September 2007, Prague, Czech Republic, 416-423.

Gribniak, V.; Kaklauskas, G.; Idnurm, S.; Bačinskas, D. 2010. Finite element mesh size effect on deformation predictions of reinforced concrete bridge girder, The Baltic Journal of Road and Bridge Engineering 5(1): 19-27.

Gumilang Jati, D. 2013. Analisis lentur pelat satu arah beton bertulang berongga bola menggunakan metode elemen hingga non linier, in Proc. of Konferensi Nasional Teknik Sipil 7 (KoNTekS 7), 24-26 October 2013, Malaysia.

Hai, L. V.; Hung, V. D.; Thi, T. M.; Nguyen-Thoi, T.; Phuoc, N. T. 2013. The experimental analysis of bubbledeck slab using modified elliptical balls, in Proc. of the Thirteenth East Asia-Pacific Conference on Structural Engineering and Construction (EASEC-13), 11-13 September 2013, Sapporo, Japan. 9 p.

Lourenço, P. B. 1996. A user/programmer's guide for the micro-modeling of masonry structures. TU Delft, report no. 03.21.1.31.35. Delft University of Technology, Delft, the Netherlands.

Marais, C. C.; Robberts, J. M.; van Rensburg, B. W. J. 2010. Spherical void formers in concrete slabs, Journal of the South African Institution of Civil Engineering 52(2): 2-11.

MC90. 1993. CEB-FIB Model Code 1990 for concrete structures, CEB Bulletin d'Information, No. 213/214, Comité Euro-International du Béton. Lausanne.

Ordon-Beska, B. 2012. Porównanie materiałochłonności stropu żelbetowego pełnego i stropu bubbledeck, Budownictwo o Zoptymalizowanym Potencjale Energetycznym 1(9): 77-83.

Sandoval, C.; Roca, P. 2012. Study of the influence of different parameters on the buckling behaviour of masonry walls, Construction and Building Materials 35: 888-899. http://dx.doi.org/10.1016/j.conbuildmat.2012.04.053

Santa Cruz Astorqui, J.; del Río Merino, M.; Cachero Alonso, G.; Monje García, I.; Rubio Madueño, D. 2009. Fissure analysis in one-directional slabs with on-site concrete rib by continuous formwork, Construction and Building Materials 23(7): 2567-2579.

http://dx.doi.org/10.1016/j.conbuildmat.2009.02.020

Schnellenbach-Held, M.; Pfeffer, K. 2002. Punching behavior of biaxial hollow slabs, Cement and Concrete Composites 24(6): 551-556. http://dx.doi.org/10.1016/S0958-9465(01)00071-3

Sergiu, C.; Sergiu, B. 2011. Nonlinear finite elements modeling of spherical voided bi-axial concrete floor slabs, in Proc. of International Symposium of Computational Civil Engineering, 81-92.

Sprince, A.; Fischer, G.; Pakrastinsh, L.; Korjakins, A. 2013. Crack propagation in concrete with silica particles, Advanced Materials Research 842: 470-476.

http://dx.doi.org/10.4028/www.scientific.net/AMR.842.470

Sprince, A.; Pakrastins, L.; Korjakins, A. 2011. Experimental study on creep of new concrete mixtures, in Proc. of the $3^{\text {rd }}$ International Conference Civil Engineering 2011, 20-26.

TNO Diana. 2011. DIANA finite element analysis, User's Manual. The Netherlands.

Yang, W.; Yang, Y.; Han, B.; Jiang, P. 2013. Experimental study on mechanical property of corner columns supported reinforced concrete honeycombed-core girderless floor, The Open Civil Engineering Journal 7: 179-188. http://dx.doi.org/10.2174/1874149501307010170 
Juozas VALIVONIS. Prof., Dr at the Department of Reinforced Concrete and Masonry Structures, Vilnius Gediminas Technical University (VGTU). Publications: the author and co-author of more than 92 scientific publications, 4 textbooks, 12 course books. Research interests: theory of reinforced concrete behaviour, composite structures, reinforced concrete bridges.

Bronius JONAITIS. Doctor, Associate Professor at the Department of Reinforced Concrete and Masonry Structures, Vilnius Gediminas Technical University. Research interests: theory of reinforced concrete behaviour, masonry and masonry constructions, composite structures, strengthening of structures.

Robertas ZAVALIS. Doctor, Assistant at the Department of Reinforced Concrete and Masonry Structures, Vilnius Gediminas Technical University. Research interests: reinforced concrete, masonry and masonry constructions.

Tomas SKUTURNA. Doctor, Associate Professor at the Department of Reinforced Concrete and Masonry Structures, Vilnius Gediminas Technical University. Research interests: theory of reinforced concrete behaviour, composite structures, strengthening of reinforced concrete structures.

Arnoldas ŠNEIDERIS. Doctor, Associate Professor at the Department of Reinforced Concrete and Masonry structures at Vilnius Gediminas Technical University. Research interests: strengthening of reinforced concrete and masonry structures; behaviour of concrete and reinforced concrete in the fire temperatures; an experimental test of materials and structures. 